\title{
Cryosurgery for the treatment of pediatric plunging ranula: a conservative management
}

\author{
Criocirurgia para tratamento de rânula mergulhante em criança: uma abordagem conservadora
}

Paulo de Camargo Moraes ${ }^{1}$

Rubens Gonçalves Teixeira'

Luiz Alexandre Thomaz ${ }^{1}$

José Luiz Cintra Junqueira'

Luciana Butini Oliveira'

\begin{abstract}
Several methods of treatment for plunging ranulas have been described in the literature, such as: surgical treatment including the excision of the sublingual gland followed by transoral drainage of the pluging ranula, needle aspiration, excision of the ranula, cryosurgery and CO(2) laser excision. Marsupialization and micro-marsupialisation can be also recommended primarily to treat oral ranulas. The aim of this paper is to present the treatment of pediatric ranula with liquid nitrogen cryosurgery performed in a 8 year, 6-month-old male, without local anesthesia. We have outlined the current protocol of cryosurgery recommended in the management of ranulas, both clinical advantages and disadvantages, with emphasis on the clinical outcomes and also pediatric patients' safety. At the 1year follow-up visit, the lesion had disappeared completely. There was no recurrent lesion. Liquid nitrogen cryosurgery for management of ranulas may become a primary treatment modality prior to surgery in children.
\end{abstract}

Indexing terms: Child. Ranula. Sublingual gland. Surgery. Treatment.

\section{RESUMO}

Muitas modalidades de tratamento têm sido propostas para o tratamento da rânula mergulhante, dentre elas: tratamento cirúrgico incluindo a excisão da glândula sublingual seguida da drenagem transoral da rânula mergulhante, aspiração, e criocirurgia e excisão com laser de CO2. Além dessas modalidades, a marsupialização e micro-marsupialização também podem ser recomendadas para o tratamento de rânulas intraorais. O objetivo deste trabalho será apresentar um caso clínico de rânula mergulhante em um paciente infantil de 8 anos e 6 meses de idade. A lesão foi tratada por meio do uso da criocirurgia, realizada com nitrogênio líquido e sem a aplicação de anestesia local. Serão destacados o protocolo de utilização, vantagens e desvantagens, resultados alcançados e a segurança para o paciente durante o tratamento. Após um ano de acompanhamento, observou-se que a lesão desapareceu completamente e não houve recidiva. Pode-se concluir que o uso da crioterapia com nitrogênio líquido pode ser o tratamento de escolha em relação à cirurgia convencional em pacientes pediátricos.

Termos de indexação: Criança. Rânula. Glândula sublingual. Cirurgia. Tratamento.

\section{INTRODUCTION}

Ranulas are large retention phenomena that occur in the floor of the mouth in relation to the sublingual gland and they can be classified into 2 groups: simple and plunging ranula. The simple (intraoral) ranula is much more common than the plunging (cervical) type ${ }^{1}$. According to Jain et al. $^{2}$ plunging ranulas are pseudocysts that originate in the sublingual salivary gland and extend to the submandibular space and then into deeper cervical spaces like the paraphayngeal space.

Pediatric plunging ranula is rare, with only a few reports in the literature ${ }^{3}$. Several methods of treatment for plunging ranulas have been described in the literature.
Primary treatment of plunging ranula has consisted of removal of the sublingual gland with excision or suction of the ranula $a^{3-4}$. Another surgical treatment options are needle aspiration, excision of the ranula, cryosurgery, andin addition to excision of the cyst-removal of the ipsilateral sublingual gland ${ }^{5}$ and $\mathrm{CO}(2)$ laser excision.

Pandit and Parker ${ }^{6}$ reported optimal management of pediatric oral cavity ranulas may include observation for 5 months for spontaneous resolution. If the lesion does not resolve or recurs repeatedly, surgical treatment is recommended.

Nonsurgical therapies have been attempted to avoid surgery-related morbidities among which insufficient removal and recurrence, and the risk of damage to

\footnotetext{
${ }^{1}$ Faculdade São Leopoldo Mandic - Rua José Rocha Junqueira, 13, Swift, 13045-755, Campinas, SP, Brasil. Correspondência para / Correspondence to: LB OLIVEIRA. E-mail:<luciana.butini@slmandic.edu.br>.
} 
the submandibular duct and lingual nerve in surgery procedures. Roh and $\mathrm{Kim}^{7}$ assessed the efficacy of OK-432 sclerotherapy for pediatric plunging ranula. Nine children with plunging ranula were prospectively treated with intracystic injections of OK-432. At the outpatient clinic, the ranula was punctured in the neck and aspirated mucus was replaced with 0.1-0.2 OK-432 solution. The authors concluded that the OK-432 sclerotherapy is safe and effective in the treatment of plunging ranula.

Cryosurgery or cryotherapy, defined as the deliberate destruction of tissue by application of extreme cold, is another therapeutic alternative for treating plunging ranulas. Few studies have described this approach toward management in pediatric patients.

This paper presents the cryosurgery as an alternative therapy to treat pediatric plunging ranula. We have outlined the current protocol recommended in the management of plunging ranulas, clinical advantages, with emphasis on the clinical outcomes and also pediatric patients' safety.

\section{CASE REPORT}

A 8 year, 6-month-old male patient was referred with a "ball" in the floor of the mouth which had been present 4 weeks before. On the extraoral examination a right-sided plunging ranula was observed (Figure 1). On the oral examination a blue translucent swelling in the floor of the mouth was presented, the lesion had a sessile base, flaccid consistency, clearly defined limits. It was measuring about $3 \mathrm{~cm}$ (Figure 2).

After signed informed consent from the parents, the treatment was performed. Considering his age and fearful behavior, the option of treatment was direct spray application of liquid nitrogen without local anesthesia (Figure 3). A cryoprobe was attached to the liquid nitrogen spray equipment. The lesion was exposed directly to 4 consecutive freeze-thaw cycles. Each cycle of 5 to $10 \mathrm{sec}$, beginning at the center of the lesion, then all the borders until the lesion appeared white and frozen (ice-ball). The Figure 4 shows the clinical appearance 12 days after the procedure. The lesion had not disappeared completely and a secondary application was performed, using the same method. At the 1year follow-up visit, the lesion had disappeared completely (Figures 5 and 6 ).

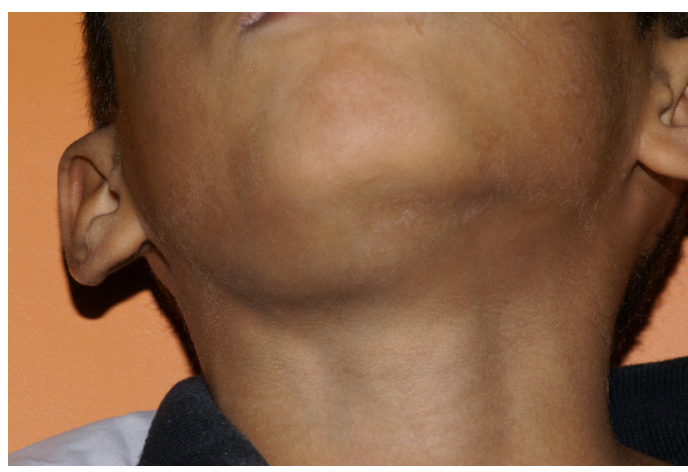

Figure 1. Extraoral view of plunging ranula of a 8 year, 6-month-old male patient. The mucus collection is in the infra mylohyoid compartment of the neck.

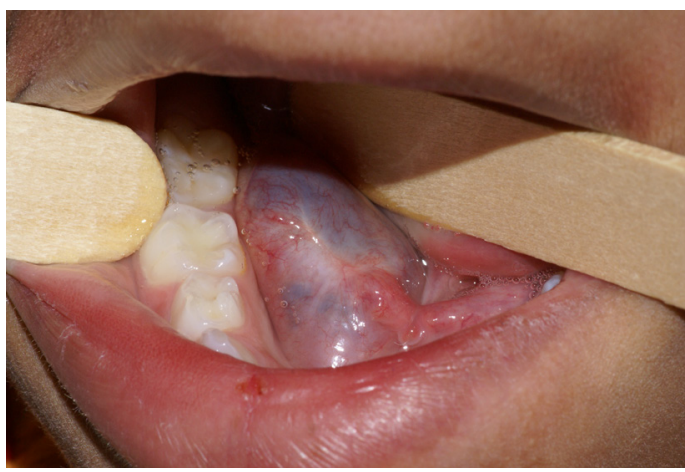

Figure 2. Intraoral view of plunging ranula.

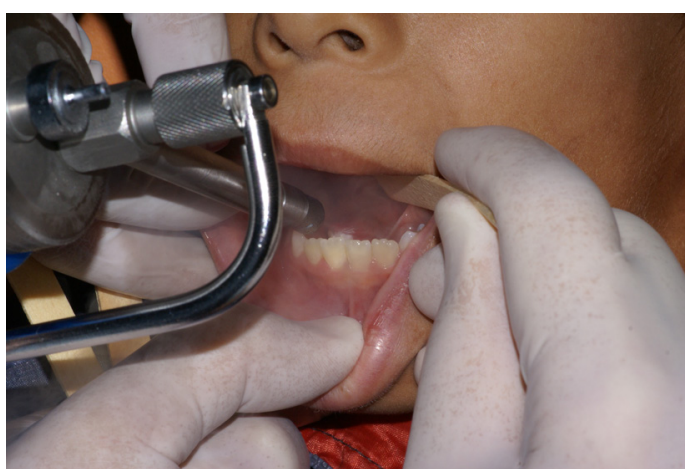

Figure 3. Direct spray application of liquid nitrogen during the treatment.

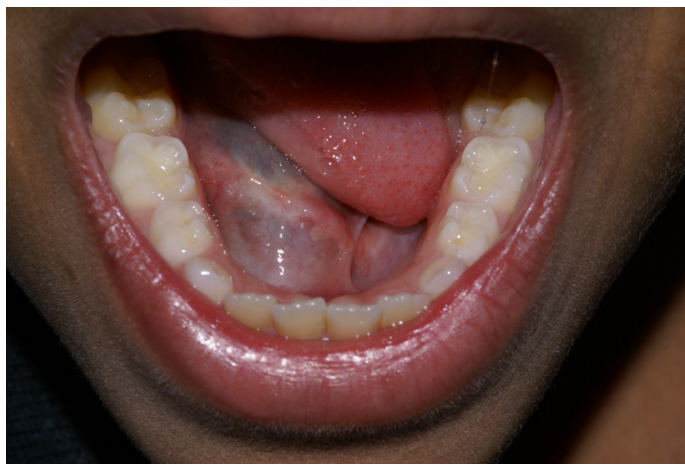

Figure 4. Appearance of lesion 12 days after treatment. The lesion had not disappeared completely and it was treated a second time with cryosurgery. 


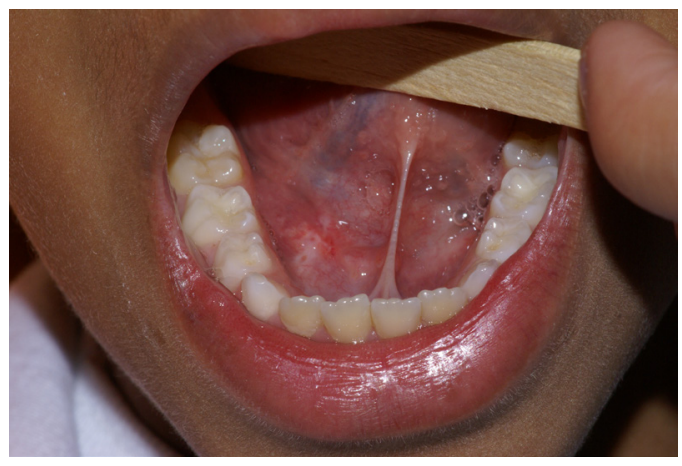

Figure 5. Clinical aspect after 1 year. Complete disappearance of the lesion without scar formation.

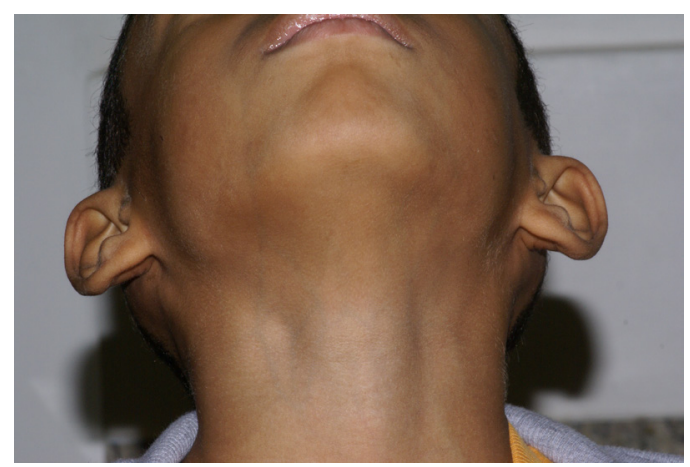

Figure 6. Extraoral view of plunging ranula. Complete disappearance of the lesion.

\section{DISCUSSION}

Different treatments to manage pluging ranula have been described in the literature. Some authors ${ }^{15}$ mentioned that a logical treatment is excision of the sublingual gland followed by transoral drainage of the pluging ranula. Marsupialization, cryosurgery, $\mathrm{CO}(2)$ laser excision ${ }^{5}$ and micro-marsupialisation can be also recommended primarily to treat oral ranulas ${ }^{8}$. Although surgery is the first choice of therapy for plunging ranula, it is associated with technical difficulties mainly in pediatric patients. In addition, a recent review of literature revealed many diverse methods of treating ranula, with varying results. 81 cases of plunging ranula were treated surgically by transoral excision of sublingual gland and evacuation of ranula contents. Mean operating time was $75.3 \mathrm{~min}$. Twelve patients had undergone previous surgery elsewhere. One patient in our series had a recurrence, needing excision of sublingual gland remnant. Two patients had trauma to submandibular duct requiring excision of submandibular gland. Other complications were minor and transient ${ }^{9}$.
Nonsurgical and minimal invasive therapies have been attempted to avoid surgery-related morbidities. OK432 sclerotherapy is safe and effective in the treatment of plunging ranula ${ }^{7}$. In the present case report, the treatment consisted of direct spray application of liquid nitrogen according the following protocol: a single application with 4 consecutive freeze-thaw cycles. However, the patient returned for 2 weeks postoperative evaluation and the clinical examination showed that the lesion had not disappeared completely. A secondary application was performed. Standard recommendations for mucoceles and ranulas include cryoprobe technique, 10 seconds (freeze time) 1 freeze-thaw cycle, margin $<1 \mathrm{~mm}$ and only a single treatment session ${ }^{10}$. It is important to emphasize that the dose of liquid nitrogen and the choice of delivery method (direct sprays technique, the rotary or spiral pattern, and the paintbrush method) depend on the size, tissue type, and depth of the lesion. Cryosurgery has advantages over the conventional treatment of the ranulas (surgical treatment) and it is extremely useful in patients for whom surgery is contra-indicated due to either medical history or age. This treatment has certain advantages over surgery mainly in children. The technique is easily performed, effective, painless, requires no expensive supplies or injectable anesthesia, patients do not have to return for suture removal and it is better tolerated by fearful children ${ }^{10-16}$. These are the major advantages in Pediatric Dentistry. Surgical excision and sutures can make children and parents anxious. It is also well received by patients due to the absence of bleeding and minimal to no scarring. ${ }^{10,13}$ In addition, cryosurgery is a cheap and a safe treatment suitable for office based practice ${ }^{15}$. It is important to emphasize that the initial cost of equipment and training should be considered.

The main disadvantage of this technique is the lack of a specimen to be examined microscopically in order to confirm the diagnosis ${ }^{10}$. Other disadvantages include unpredictable degree of swelling and lack of precision with depth and area of freezing. It also is highly dependent on operator skill and experience. Although, a cryoprobe attached to the liquid nitrogen spray gun can provide added versatility, depending on the site and types of the lesion. The cryoprobe is applied directly to the lesions and it is available in various sizes and types ${ }^{11}$.

In the present case report cryosurgery technique was performed without local anesthesia or any sedative 
agent considering lesions size and easy localization, short necessary chair time. Cryosurgery provided to be a conservative treatment and the lesion disappeared completely with no evidence of scarring. Liquid nitrogen cryosurgery for management of pluging ranulas may become a primary treatment modality prior to surgery in children.

\section{REFERENCES}

1. Zhi $\mathrm{K}$, Wen $\mathrm{Y}$, Zhou $\mathrm{H}$. Management of the pediatric plunging ranula: results of 15 years' clinical experience. Oral Surg Oral Med Oral Pathol Oral Radiol Endod. 2009;107(4):499-502. doi: 10.1016/j.tripleo.2008.09.023

2. Jain $\mathrm{P}$, Jain $\mathrm{R}$, Morton RP, Ahmad Z. Plunging ranulas: highresolution ultrasound for diagnosis and surgical management. Eur Radiol. 2010;20(6):1442-9. doi: 10.1007/s00330-0091666-1

3. Mahadevan M, Vasan N. Management of pediatric plunging ranula. Int J Pediatr Otorhinolaryngol. 2006;70(6):1049-54. doi: 10.1016/j.jporl.2005.10.022

4. Habernal H, Göçmen, E. Surgical management of pediatric ranula. Int J Pediatr Otorhinolaryngol. 2004;68(2):161-3. doi: 10.1016/j.ijporl.2003.09.017

5. Bernhard MK, Hückel D, Hamala D. Congenital ranula in a newborn. HNO. 2007;55(5):388-91. doi: 10.1007/s00106-0061409-4

6. Pandit RT, Park AH. Management of pediatric ranula. Otolaryngol Head Neck Surg. 2002;127(1):115-8. doi: 10.1067/ mhn.2002.126590

7. Roh JL, Kim HS. Primary treatment of pediatric plunging ranula with nonsurgical sclerotherapy using OK-432 (Picibanil $($ )). Int J Pediatr Otorhinolaryngol. 2008;72(9):1405-10. doi: 10.1016/j. ijporl.2008.06.003

8. Amaral MB, de Freitas JB, Mesquita RA. Upgrading of the micromarsupialisation technique for the management of mucus

\section{Collaborators}

PC MORAES, RG TEIXEIRA and LA THOMAZ assisted the patient in the case here reported and in writing the draft of the paper. JLC JUNQUEIRA and LB OLIVEIRA participated in writing the paper and in its submission to this journal.

extravasation or retention phenomena. Int J Oral Maxillofac Surg. 2012;41(12):1527-31. doi: 10.1016/j.ijom.2012.04.01

9. Samant S, Morton RP, Ahmad Z. Surgery for plunging ranula: the lesson not yet learned? Eur Arch Otorhinolaryngol. 2011;268(10):1513-8. doi: 10.1007/s00405-011-1509-y

10. Farah CS, Savaget NW. Cryotherapy for treatment of oral lesions. Aus Dent J. 2006;51(1):2-5.

11. Andrews MD. Cryosurgery for common skin conditions. Am Fam Physician. 2004;69(10):2365-72.

12. Moraes Pde C, Teixeira RG, Thomaz LA, Arsati F, Junqueira $J \mathrm{~L}$, Oliveira LB. Liquid nitrogen cryosurgery for treatment of mucoceles in children. Pediatr Dent. 2012;34(2):159-61.

13. Toida M, Ishimaru Jl, Hobo N. A simple cryotherapy method for treatment of oral mucous cysts. Int J Oral Maxillofac Surg. 1993;22(6):353-5.

14. Cooper SM, Dawber RP. The history of cryosurgery. JR Soc Med. 2001;94(4):196-201.

15. Mizuno A, Yamaguchi K. The plunging ranula. Int J Oral Maxillofac Surg. 1993;22:113-5.

16. Rezende KM, Moraes PC, Oliveira LB, Thomaz LA, Junqueira JL, Bönecker M. Cryosurgery as an effective alternative for treatment of oral lesions in children. Braz Dent J. 2014;25(4):352-6. doi: 10.1590/0103-6440201302254

Received on: 9/7/2015

Final version resubmitted on: 24/8//2015

Approved on: 10/9/2015 